\title{
Efektivitas Penggunaan Multimedia Interaktif Materi Kalor Berorientasi Peta Kompetensi Siswa Sekolah Menengah Atas
}

\author{
Saprudin $^{1 *}$, dan Fatma Hamid ${ }^{2}$ \\ 1,2 Program Studi Pendidikan Fisika, FKIP, Universitas Khairun \\ `E-mail: Saprudin_unkhair@yahoo.com
}

\begin{abstract}
Abstrak
Artikel ini merupakan bagian dari penelitian pengembangan model multimedia pembelajaran fisika berorientasi peta kompetensi siswa Sekolah Menengah Atas (SMA) di provinsi Maluku Utara. Penelitian ini bertujuan untuk menyelidiki efektivitas penggunaan multimedia interaktif (MMI) dalam meningkatkan penguasaan konsep fisika siswa SMA khususnya pada materi kalor. Penelitian eksperimen ini menggunakan randomized control group pretest-posttest design dengan sampel siswa kelas X pada salah satu SMA di Kabupaten Halmahera Barat. Pengumpulan data dilakukan melalui tes yakni uji kompetensi siswa yang berisi kemampuan yang diujinasionalkan terkait materi kalor. Hasil perhitungan Effect Size menunjukkan bahwa besarnya Cohen's $d$ effect size antara kelas eksperimen 1 dengan kelas kontrol sebesar 3,7 (tinggi) dan antara kelas eksperimen 2 dengan kelas kontrol sebesar 0,7 (sedang). Hal ini berarti bahwa penggunaan MMl secara signifikan efektif dalam meningkatkan kompetensi siswa pada kemampuan yang diujinasionalkan khususnya pada materi kalor. Besarnya effect size menunjukkan bahwa implementasi MMI lebih efektif jika digunakan dalam pembelajaran dengan menerapkan model pembelajaran tertentu dalam hal ini model pembelajaran kooperatif tipe Student Team Achievement Division (STAD).
\end{abstract}

Kata kunci: Efektivitas, Multimedia Interaktif, Penguasaan Konsep, Kalor.

\section{PENDAHULUAN}

Seiring perkembangan ilmu pengetahuan dan teknologi, berbagai upaya peningkatan mutu pendidikan terus menerus dilakukan demi tercapainya tujuan pendidikan yang telah ditetapkan. Akreditasi sekolah merupakan salah satu upaya pengawasan penjaminan mutu pendidikan. Standar proses merupakan bagian dari delapan standar nasional pendidikan yang menjadi komponen penilaian akreditasi sekolah. Salah satu item penilaian dalam standar proses adalah penggunaan ragam media pembelajaran yang digunakan guru dalam proses pembelajaran (Rahman, dkk, 2017).

Media berasal dari bahasa latin yakni medius yang secara harfiah berarti 'tengah', 'perantara' atau 'pengantar' (Arsyad, 2010). Munadi (2008) menyatakan bahwa media pembelajaran merupakan segala sesuatu yang dapat menyampaikan dan menyalurkan pesan dari sumber secara terencana sehingga tercipta lingkungan belajar yang kondusif dimana penerimanya dapat melakukan proses belajar secara efektif dan efisien.

Fisika merupakan salah satu mata pelajaran pada ujian nasional (UN) SMA program IPA yang secara umum dianggap sulit untuk dikerjakan oleh siswa SMA. Tahun 2012, pada UN SMA program IPA ditemukan sebanyak 288 peserta dari 4837 peserta di Provinsi Maluku Utara yang dinyatakan tidak lulus UN (BSNP, 2012). Salah satu penyebab ketidaklulusan siswa SMA di provinsi Maluku Utara adalah rendahnya penguasaan siswa terhadap konsep-konsep pada kompetensi yang diujinasionalkan yang dapat teridentifikasi melalui hasil UN pada setiap tahunnya.

Materi kalor merupakan salah satu materi fisika SMA yang ditemukan masih lemah capaian kompetensinya. Di sisi lain, materi ini juga merupakan salah satu materi yang masih lemah capaian kompetensinya pada level perguruan tinggi yakni pada mahasiswa calon guru fisika di provinsi Maluku Utara. Beberapa indikator yang teridentifikasi masih lemah diantaranya adalah indikator menentukan laju kalor pada peristiwa konduksi, menentukan perbandingan jumlah kalor yang harus diberikan pada kedua jenis benda yang memiliki massa, kalor jenis dan kenaikan suhu tertentu, menentukan banyaknya kalor yang dibutuhkan untuk meleburkan suatu es dengan massa dan suhu tertentu (Saprudin, et. al., 2017).

Hasil analisis konsep menunjukkan bahwa materi kalor secara umum didominasi oleh label 
konsep abstrak dan label konsep yang menunjukkan proses sehingga siswa mengalami kesulitan untuk memahaminya. Oleh karena itu, guru dituntut untuk memilih dan menerapkan pendekatan, metode atau model pembelajaran yang sesuai serta mengemas materi pembelajaran yang dapat memotivasi siswa untuk belajar dan juga dapat mempermudah siswa untuk memahaminya.

Salah satu upaya yang dapat dilakukan untuk mengatasi permasalahan di atas adalah melalui penggunaan multimedia interaktif dalam pembelajaran kalor pada pembelajaran fisika di SMA. Dalam konteks komputer, Hofstetter (Munir, 2012) menyatakan bahwa multimedia adalah penggunaan komputer untuk menyajikan dan menggabungkan teks, suara, gambar, animasi dan video dengan alat bantu (tool) dan koneksi (link) sehingga pengguna dapat melakukan navigasi, berinteraksi, berkarya dan berkomunikasi. Multimedia kalor dalam penelitian ini merupakan multimedia model tutorial. Rusman (2012) mendefinisikan tutorial sebagai bimbingan pembelajaran dalam bentuk pemberian arahan, bantuan, petunjuk dan motivasi agar para siswa belajar secara efisien dan efektif. Pemberian bantuan berarti membantu siswa dalam mempelajari materi pelajaran. Petunjuk berarti memberikan informasi tentang cara belajar secara efektif dan efisien. Arahan berarti mengarahkan siswa untuk mencapai tujuan masing-masing. Motivasi berarti menggerakkan kegiatan para siswa dalam mempelajari materi, mengerjakan tugas-tugas dan mengikuti penilaian. Bimbingan berarti membantu para siswa memecahkan masalah-masalah belajar.

Adanya penggunaan MMI kalor dalam pembelajaran fisika SMA diharapkan dapat membantu memvisualisasi konsep-konsep abstrak serta dapat memvisualisasikan fenomena atau proses fisis yang tidak dapat diamati oleh mata secara langsung sehingga siswa dapat lebih mudah untuk memahami materi kalor terutama konsep-konsep esensial yang biasanya menjadi bagian dari kemampuan yang diujikan pada UN SMA.

Dalam implementasinya, penggunaan multimedia interaktif dalam pembelajaran tentunya perlu ditunjang dengan sarana dan prasarana yang mendukung terutama fasilitas terkait listrik dan komputer. Penggunaan multimedia interaktif biasanya mengalami kendala ketika diimplementasikan pada sekolah dengan sarana dan prasarana yang kurang memadai (Saprudin, 2015). Oleh karena itu, tentunya perlu pemilihan strategi implementasi multimedia interaktif yang dikembangkan pada sekolah dengan kondisi tersebut.

Model pembelajaran kooperatif Student Teams Achievement Divisions (STAD) merupakan salah satu model pembelajaran yang dapat diterapkan untuk menjembatani permasalahan tersebut. Slavin (2008) mengemukakan bahwa dalam kooperatif STAD para siswa dibagi dalam tim belajar yang terdiri atas empat orang yang berbeda-beda tingkat kemampuannya, jenis kelamin dan latar belakang etniknya. Guru menyampaikan pelajaran, lalu siswa bekerja dalam tim mereka untuk memastikan bahwa semua anggota tim telah menguasai pelajaran. Selanjutnya semua siswa mengerjakan kuis mengenai materi secara sendiri-sendiri dimana saat itu mereka tidak diperbolehkan untuk saling bantu. Siswa selanjutnya akan mengumpulkan poin untuk tim mereka berdasarkan tingkat kenaikan skor kuis mereka dibandingkan dengan skor awal mereka. Setiap tim akan mendapatkan sertifikat atau bentuk penghargaan yang lain apabila skor rata-rata mereka mencapai kriteria tertentu. STAD merupakan salah satu metode yang paling sederhana dan merupakan model yang paling baik bagi para guru yang baru menggunakan pembelajaran kooperatif. STAD terdiri atas lima komponen utama yakni; Presentasi kelas, tim, kuis, skor kemajuan individu dan rekognisi tim.

\section{METODE/EKSPERIMEN}

Metode penelitian yang digunakan adalah metode eksperimen dengan desain randomized control group pretest-posttest design.

Tabel 1. Desain Penelitian

\begin{tabular}{cccc}
\hline Group & Pretest & Treatment & Posttest \\
\hline First Exp. Group $R_{1}$ & $\mathrm{~T}_{1}$ & Model kooperatif STAD & $\mathrm{T}_{2}$ \\
& & Berbasis MMI & MMl \\
Second Exp. Group $R_{2}$ & $\mathrm{~T}_{3}$ & Model Konvensional & $\mathrm{T}_{4}$ \\
Control Group $R_{3}$ & $\mathrm{~T}_{5}$ & $\mathrm{~T}_{6}$ \\
\hline
\end{tabular}


Penelitian ini dilakukan pada siswa kelas X pada salah satu SMA di Kabupaten Halmahera Barat yang tersebar ke dalam tiga kelas. Data dikumpulkan melalui tes yakni uji kompetensi siswa yang berisi kemampuan yang diujinasionalkan khususnya pada materi kalor. Analisis data dilakukan dengan analisis statistik parametrik.

Peningkatan penguasaan konsep siswa dapat dihitung dengan menghitung besarnya skor gain yang dinormalisasi dengan menggunakan rumus yang dikembangkan oleh Hake (1998) yaitu;

$$
<g>=\frac{\%<S_{f}>-\%<S_{i}>}{100-\%<S_{i}>}
$$

dimana $S_{f}$ adalah rata-rata skor posttest dan $S_{i}$ adalah rata-rata skor pretest. Interpretasi nilai $<g>$ dapat dilihat pada tabel 2 .

Tabel 2. Interpretasi Nilai Gain Skor Ternormalisasi (Hake, 1998)

\begin{tabular}{cc}
\hline Kategori Perolehan $(<g>)$ & Keterangan \\
\hline$(<g>) \geq 0,7$ & Tinggi \\
$0,7>(<g>) \geq 0,3$ & Sedang \\
$(<g>)<0,3$ & Rendah \\
\hline
\end{tabular}

Efektivitas penggunaan MMI dalam meningkatkan kompetensi yang diujinasionalkan diukur dengan menentukan effect size yang diinterpretasikan pada kriteria Cohen (Thalheimer \& Cook, 2002; Kotrlik et. al, 2011; Nandy, 2012). dengan

$$
d=\frac{\bar{x}_{t}-\bar{X}_{c}}{s_{\text {pooled }}}
$$

$$
s_{\text {pooled }}=\sqrt{\frac{\left(n_{t}-1\right) S_{t}^{2}+\left(n_{c}-1\right) S_{c}^{2}}{n_{t}+n_{c}}}
$$

Untuk kasus khusus misalnya ukuran sampel kecil, maka besarnya standar deviasi gabungan dinyatakan dengan;

$$
S_{\text {pooled }}=\sqrt{\frac{\left(n_{t}-1\right) S_{t}^{2}+\left(n_{c}-1\right) S_{c}^{2}}{n_{t}+n_{c}-2}}
$$

\section{HASIL DAN PEMBAHASAN}

\section{Efektivitas Penggunaan MMI dalam Meningkatkan Kompetensi yang Diujinasionalkan Pada Materi Kalor}

Hasil pretest dan posttest siswa pada materi kalor yang telah diolah dengan menggunakan SPSS 16.0 dapat ditunjukkan pada tabel 3. Rata-rata nilai pretest dan posttest pada kelas eksperimen 1 adalah 19,55 dan 54,45. Untuk kelas eksperimen 2, nilai pretest dan posttest adalah 17,32 dan 35,68. Sedangkan rata-rata nilai pretest dan posttest pada kelas kontrol sebesar 17,00 dan 25,57. Berdasarkan nilai pretest dan posttest dapat ditunjukkan bahwa secara keseluruhan kompetensi siswa pada kemampuan yang diujinasionalkan khususnya pada materi kalor mengalami peningkatan setelah mengikuti pembelajaran baik pada kelas eksperimen 1, eksperimen 2 maupun pada kelas kontrol.

Uji normalitas nilai pretest dengan menggunakan One-Sample Kolmogorov-Smirnov Test menunjukkan bahwa data nilai pretest siswa pada ketiga kelas berdistribusi normal dengan signifikansi (Sig.) atau p-value sebesar 0,178 untuk kelas eksperimen 1 dan 0,178 untuk eksperimen 2 serta 0,661 untuk kelas kontrol.

Hasil uji homogenitas varians dengan menggunakan Levene Test (Test of Homogeneity of Variances) menunjukkan bahwa sebaran data pretest pada ketiga kelas berdistribusi homogen dengan signifikansi (Sig.) atau p-value sebesar 0,267. 
Tabel 3. Pengolahan Data Pretest dan Posttest Uji Kompetensi Siswa

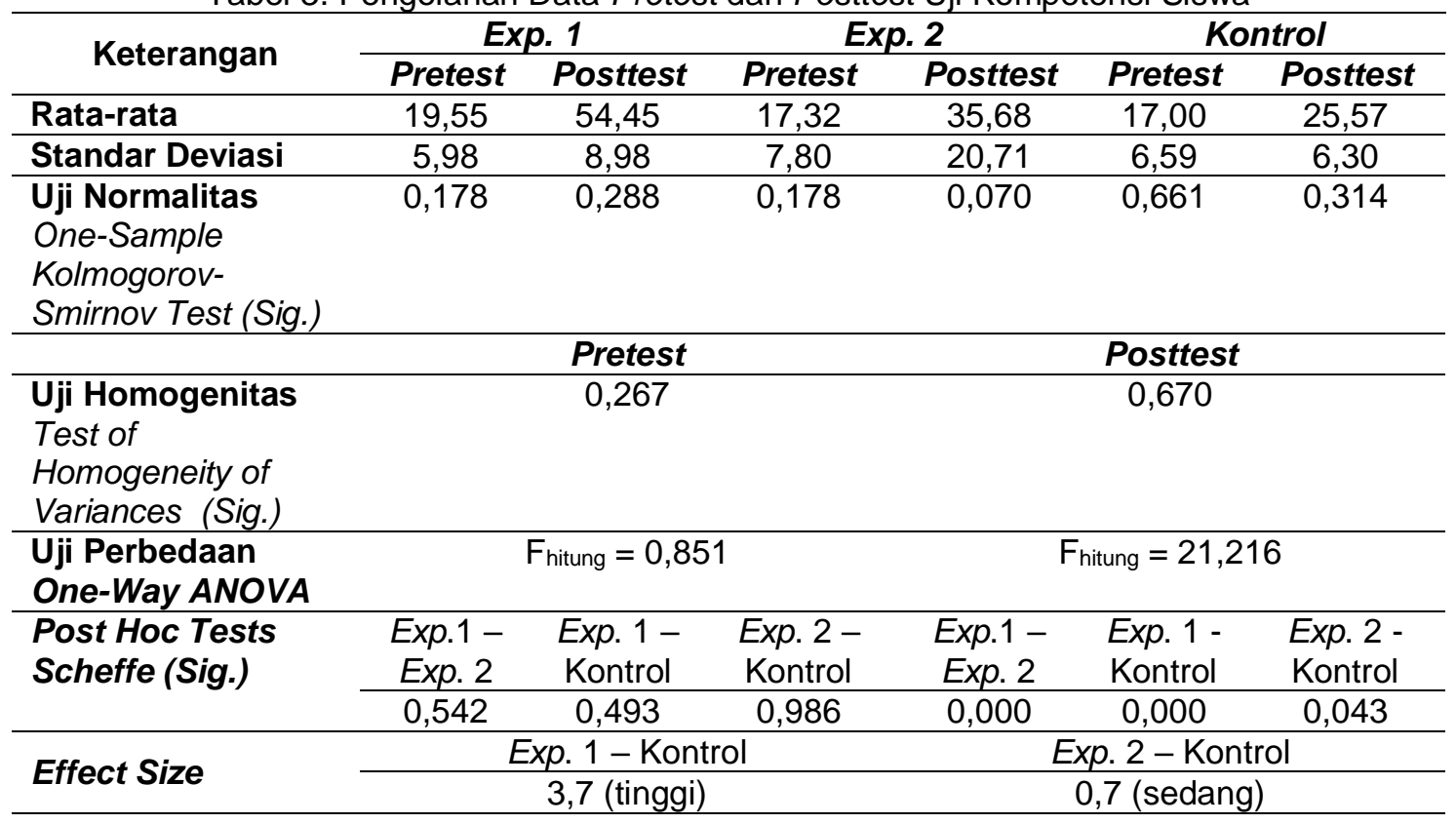

Berdasarkan hasil uji perbedaan tiga rata-rata dengan menggunakan One-Way ANOVA diperoleh bahwa nilai $F_{\text {hitung }}=0,851$ yang lebih kecil dari nilai $F_{\text {tabel }}\left(F_{(0,95)(2,71)}\right)$ sebesar 3,13 . Hal ini menunjukkan bahwa tidak terdapat perbedaan yang signifikan untuk nilai pretest pada ketiga kelas tersebut.

Hasil uji lanjut perbedaan rata-rata dengan menggunakan test Post Hoc (Uji Scheffe) diperoleh bahwa tidak terdapat perbedaan yang signifikan pada nilai pretest antara kelas eksperimen 1 dengan eksperimen 2, tidak terdapat perbedaan yang signifikan pada nilai pretest antara kelas eksperimen 1 dengan kelas kontrol dan tidak terdapat perbedaan yang signifikan pada nilai pretest antara kelas eksperimen 2 dengan kelas kontrol. Hal ini menunjukkan bahwa ketiga kelas memiliki kemampuan yang relatif sama sebelum mengikuti pembelajaran.

Setelah siswa mengikuti pembelajaran, pada ketiga kelas tersebut diberikan posttest. Hasil posttest dianalisis dengan menggunakan statistik parametrik. Hasil uji normalitas dengan menggunakan One-Sample Kolmogorov-Smirnov Test menunjukkan bahwa data nilai posttest siswa pada ketiga kelas berdistribusi normal dengan signifikansi ( Sig.) atau p-value sebesar 0,288 untuk kelas eksperimen 1 dan 0,070 untuk kelas ekspermen 2 serta 0,314 untuk kelas kontrol. Hasil uji homogenitas varians dengan menggunakan Levene Test (Test of Homogeneity of Variances) menunjukkan bahwa sebaran data nilai posttest pada ketiga kelas tersebut adalah homogen dengan signifikansi (Sig.) atau p-value sebesar 0,670.

Berdasarkan hasil uji perbedaan tiga rata-rata dengan menggunakan One-Way ANOVA diperoleh bahwa nilai $F_{\text {hitung }}=21,216$ yang lebih besar dari nilai $F_{\text {tabel }}\left(F_{(0,95)(2,71)}\right)$ sebesar 3,13 . Hal ini menunjukkan bahwa terdapat perbedaan yang signifikan pada nilai posttest pada ketiga kelas tersebut.

Berdasarkan hasil uji lanjut perbedaan rata-rata tersebut dengan test Post Hoc (Uji Scheffe) diperoleh bahwa terdapat perbedaan yang signifikan pada nilai posttest antara kelas eksperimen 1 dengan kelas eksperimen 2, antara kelas eksperimen 1 dengan kelas kontrol dan antara kelas eksperimen 2 dengan kelas kontrol.

Untuk menelusuri efektivitas penggunaan MMI dalam meningkatkan kompetensi siswa pada kemampuan yang diujinasionalkan, maka dihitung dengan menggunakan rumus Effect Size. Hasil perhitungan Effect Size menunjukkan bahwa besarnya Cohen's $d$ effect size antara kelas eksperimen 1 dengan kelas kontrol adalah 3,7 (tinggi). Sedangkan, besarnya Cohen's $d$ effect size antara kelas eksperimen 2 dengan kelas kontrol adalah 0,7 (sedang). Hal ini berarti bahwa penggunaan MMI secara signifikan efektif dalam meningkatkan kompetensi siswa pada kemampuan yang diujinasionalkan 
khususnya pada materi kalor. Dari besarnya effect size dapat ditunjukkan bahwa MMI lebih efektif bila digunakan dalam pembelajaran dengan menerapkan model pembelajaran tertentu dalam hal ini model pembelajaran kooperatif tipe STAD.

\section{Deskripsi Capaian Kompetensi Siswa untuk Setiap Kemampuan yang Diujinasionalkan Khususnya pada Materi Kalor}

Untuk kelas eksperimen 1, gambaran capaian kompetensi siswa sebelum dan setelah mengikuti pembelajaran ditunjukkan pada Gambar 1. Secara umum kompetensi siswa mengalami peningkatan setelah mengikuti pembelajaran. Capaian kompetensi tertinggi pada kelas eksperimen 1 setelah mengikuti pembelajaran terjadi pada kemampuan uji nomor 2 yakni kemampuan uji tentang mengkonversi satuan suhu dari derajat fahrenheit manjadi Kelvin. Sedangkan capaian kompetensi terendah terjadi pada kemampuan uji nomor 12 yakni tentang menentukan suhu akhir zat cair dalam proses meleburnya es yang diberikan kalor tertentu.

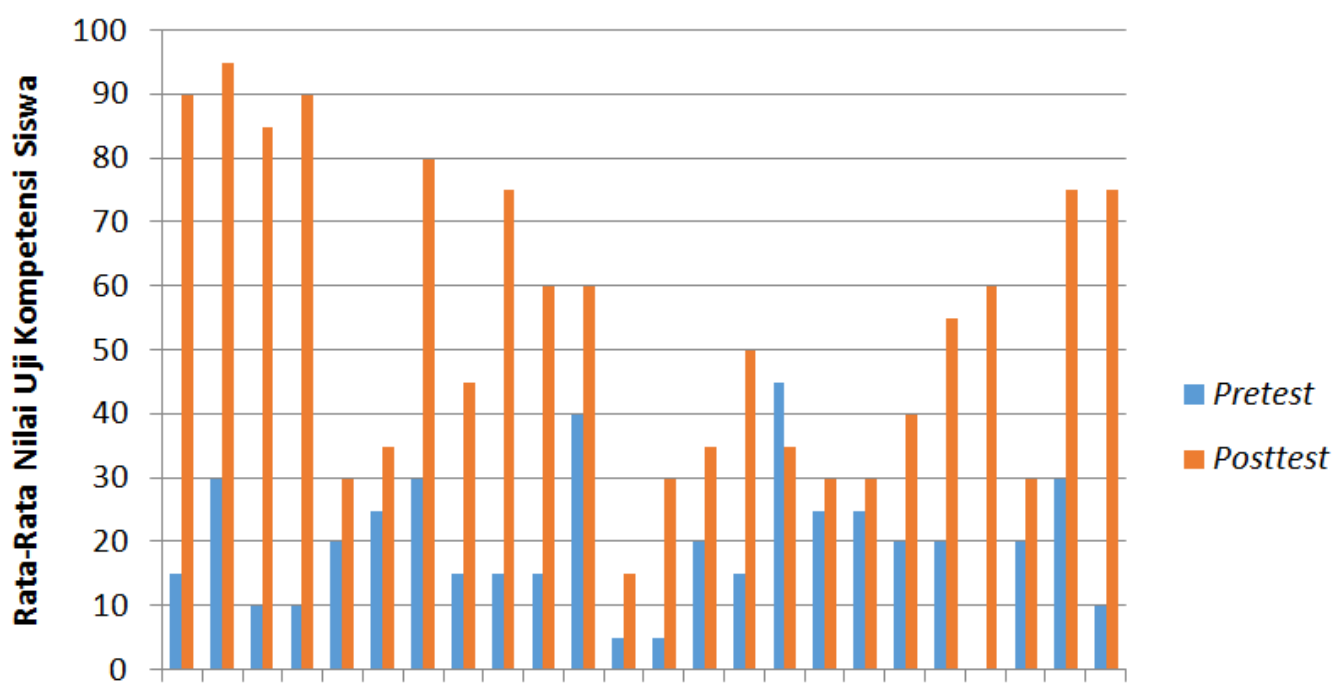

$122 \quad 3 \quad 4 \quad 5 \quad 6 \quad 7 \quad 8 \quad 9101112131415161718192021222324$

Nomor Soal

Gambar 1. Profil Capaian Kompetensi Siswa Kelas Eksperimen 1

Untuk kelas eksperimen 2, gambaran capaian kompetensi siswa sebelum dan setelah mengikuti pembelajaran ditunjukkan pada Gambar 2. Capaian kompetensi tertinggi kelas eksperimen 2 terjadi pada kemampuan uji nomor 6 yakni kemampuan uji tentang menentukan besarnya perubahan panjang sebuah logam setelah dipanaskan sampai suhu tertentu, nomor 14 tentang penerapan azas black untuk menentukan suhu setimbang jika air panas dimasukkan ke dalam bejana yang terbuat dari logam dan kemampuan uji nomor 18 yakni kemampuan uji tentang menyebutkan hubungan yang benar antara laju kalor secara konduksi dengan panjang logam, luas penampang dan perbedaan suhu antara ujungujung logam. Sedangkan capaian kompetensi terendah terjadi pada kemampuan uji nomor 13 tentang meramalkan apa yang terjadi jika es dengan suhu $0^{\circ} \mathrm{C}$ dicampukan dengan air dengan suhu $0^{0} \mathrm{C}$. 


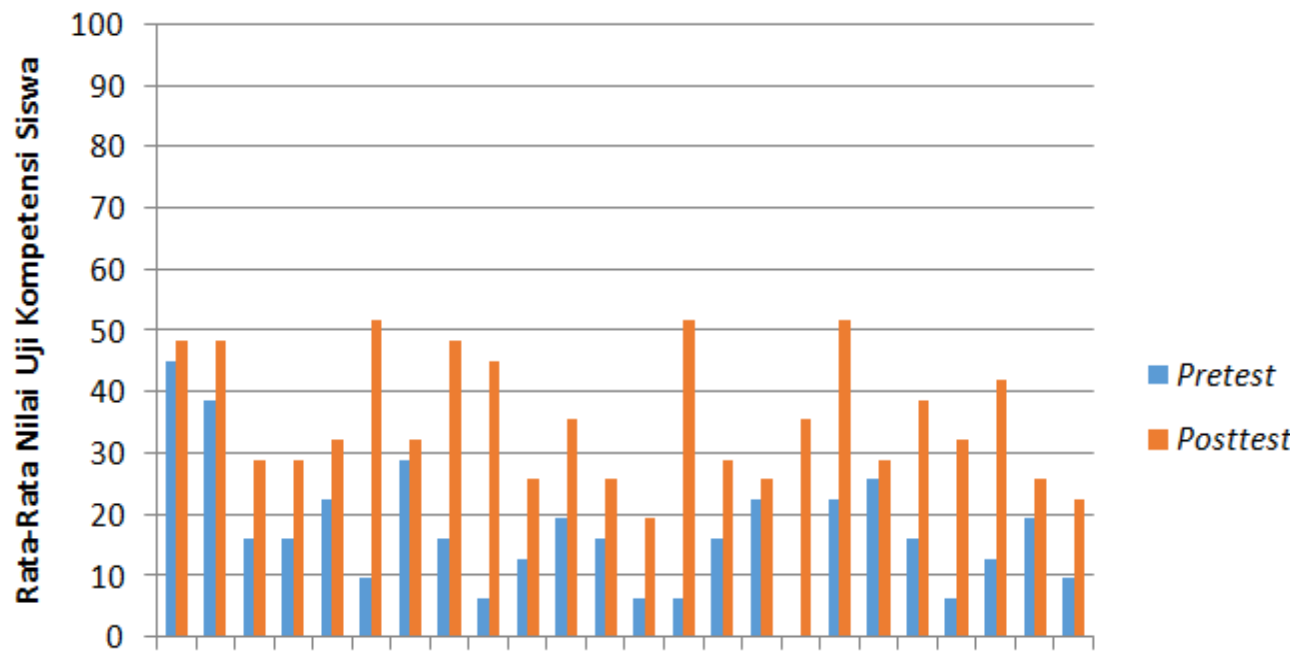

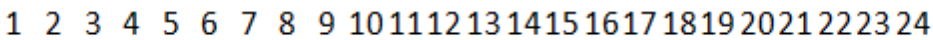

Nomor Soal

Gambar 2. Profil Capaian Kompetensi Siswa Kelas Eksperimen 2

Untuk kelas kontrol, gambaran capaian kompetensi siswa sebelum dan setelah mengikuti pembelajaran ditunjukkan pada Gambar 3.



Gambar 3. Profil Capaian Kompetensi Siswa Kelas Kontrol

Berdasarkan gambar 3, capaian kompetensi tertinggi pada kelas kontrol terjadi pada kemampuan uji nomor 2 yakni tentang mengkonversi satuan suhu dari derajat fahrenheit manjadi Kelvin, nomor 20 tentang menentukan perbandingan laju rambatan kalor secara konduksi pada dua batang yang memiliki jenis dan suhu kedua ujungnya sama tetapi luas dan panjangnya berbeda dan kemampuan uji nomor 22 tentang menentukan besarnya konduktivitas termal logam jika laju rambatan kalor, luas permukaan dan perbedaan suhu antar ujung-ujung logam diketahui. Sedangkan capaian kompetensi terendah terjadi pada kemampuan uji nomor 5 tentang mengkonversi suhu suatu benda dari satuan celcius ke satuan lainnya dan nomor 10 tentang menunjukkan faktor yang mempengaruhi kalor jenis suatu zat.

Untuk menelusuri besarnya peningkatan kompetensi siswa pada ketiga kelas untuk setiap 
kemampuan uji, maka dapat ditentukan dengan menghitung besarnya gain skor yang dinormalisasi seperti ditunjukkan pada Tabel 4.

Tabel 4. Profil Peningkatan Kompetensi Siswa Pada Materi Kalor

\begin{tabular}{|c|c|c|c|c|}
\hline No & Kemampuan Uji & $\begin{array}{l}<g> \\
\text { Kelas } \\
\text { Eks. } 1\end{array}$ & $\begin{array}{l}<g> \\
\text { Kelas } \\
\text { Eks. } 2\end{array}$ & $\begin{array}{c}<g> \\
\text { Kelas } \\
\text { Kontro }\end{array}$ \\
\hline 1 & Mengkonversi satuan suhu dari derajat celcius menjadi derajat reamur & 0,88 & 0,06 & 0,07 \\
\hline 2 & Mengkonversi satuan suhu dari derajat fahrenheit manjadi Kelvin & 0,93 & 0,16 & 0,14 \\
\hline 3 & $\begin{array}{l}\text { Menentukan nilai angka yang sama antara termometer skala fahrenheit } \\
\text { dan termometer skala reamur }\end{array}$ & 0,83 & 0,15 & 0,05 \\
\hline 4 & $\begin{array}{l}\text { Menentukan nilai angka skala dimana skala fahrenheit menunjukkan dua } \\
\text { kali skala celcius }\end{array}$ & 0,89 & 0,15 & 0,05 \\
\hline 5 & Mengkonversi suhu suatu benda dari satuan celcius ke satuan lainnya & 0,13 & 0,13 & 0,00 \\
\hline 6 & $\begin{array}{l}\text { Menentukan besarnya perubahan panjang sebuah logam setelah } \\
\text { dipanaskan sampai suhu tertentu }\end{array}$ & 0,13 & 0,46 & 0,06 \\
\hline 7 & $\begin{array}{l}\text { Menentukan suhu akhir sebatang baja jika mengalami perubahan } \\
\text { panjang tertentu setelah dipanaskan }\end{array}$ & 0,71 & 0,05 & 0,18 \\
\hline 8 & $\begin{array}{l}\text { Menentukan besarnya luas akhir plat logam setelah dipanaskan sampai } \\
\text { suhu tertentu }\end{array}$ & 0,35 & 0,38 & 0,05 \\
\hline 9 & $\begin{array}{l}\text { Menentukan banyaknya volume air raksa yang tumpah dengan } \\
\text { menerapkan konsep pemuaian volume pada bejana kaca yang diisi air }\end{array}$ & 0,71 & 0,41 & 0,11 \\
\hline 10 & Menunjukkan faktor yang mempengaruhi kalor jenis suatu zat & 0,53 & 0,15 & 0,04 \\
\hline 11 & $\begin{array}{l}\text { Menentukan banyaknya kalor yang diperlukan untuk menaikkan suhu es } \\
\text { dengan massa tertentu menjadi air dengan temperatur tertentu }\end{array}$ & 0,33 & 0,20 & 0,06 \\
\hline 12 & $\begin{array}{l}\text { Menentukan suhu akhir air yang dihasilkan dari proses meleburnya es } \\
\text { jika diberikan sejumlah kalor }\end{array}$ & 0,11 & 0,12 & 0,10 \\
\hline 13 & $\begin{array}{l}\text { Meramalkan apa yang terjadi jika es dengan suhu } 0^{\circ} \mathrm{C} \text { dicampukan } \\
\text { dengan air dengan suhu } 0^{\circ} \mathrm{C}\end{array}$ & 0,26 & 0,14 & 0,05 \\
\hline 14 & $\begin{array}{l}\text { Menerapkan azas black untuk menentukan suhu setimbang jika air } \\
\text { panas dimasukkan ke dalam bejana yang terbuat dari logam }\end{array}$ & 0,19 & 0,48 & 0,10 \\
\hline 15 & $\begin{array}{l}\text { Menerapkan azas black untuk menentukan suhu setimbang jika logam } \\
\text { alumunium dimasukkan ke dalam air panas dengan suhu tertentu }\end{array}$ & 0,41 & 0,15 & 0,11 \\
\hline 16 & $\begin{array}{l}\text { Menerapkan azas black untuk menentukan besarnya massa air panas } \\
\text { yang harus ditambahkan pada air dingin untuk mencapai suhu } \\
\text { kesetimbangan tertentu }\end{array}$ & $-0,18$ & 0,04 & 0,09 \\
\hline 17 & $\begin{array}{l}\text { Menerapkan azas black untuk menentukan suhu kesetimbangan jika } \\
\text { susu dimasukkan ke dalam kalorimeter yang berisi kopi dengan suhu } \\
\text { tententu }\end{array}$ & 0,07 & 0,35 & 0,06 \\
\hline 18 & $\begin{array}{l}\text { Menyebutkan hubungan yang benar antara laju kalor secara konduksi } \\
\text { dengan panjang logam, luas penampang dan perbedaan suhu antara } \\
\text { ujung-ujung logam }\end{array}$ & 0,07 & 0,37 & 0,16 \\
\hline 19 & $\begin{array}{l}\text { Menjelaskan bahwa perpindahan kalor secara konveksi hanya terjadi } \\
\text { pada zat cair dan gas }\end{array}$ & 0,25 & 0,04 & 0,05 \\
\hline 20 & $\begin{array}{l}\text { Menentukan perbandingan laju rambatan kalor secara konduksi pada } \\
\text { dua batang yang memiliki jenis dan suhu kedua ujungnya sama tetapi } \\
\text { luas dan panjangnya berbeda }\end{array}$ & 0,44 & 0,27 & 0,20 \\
\hline 21 & $\begin{array}{l}\text { Menentukan laju rambatan kalor secara konduksi jika besaran fisika } \\
\text { yang lainnya diketahui }\end{array}$ & 0,60 & 0,28 & 0,29 \\
\hline 22 & $\begin{array}{l}\text { Menentukan besarnya konduktivitas termal logam jika laju rambatan } \\
\text { kalor, luas permukaan dan perbedaan suhu antar ujung-ujung logam } \\
\text { diketahui }\end{array}$ & 0,13 & 0,33 & 0,33 \\
\hline 23 & $\begin{array}{l}\text { Menentukan perbandingan laju rambatan kalor secara konduksi pada } \\
\text { dua logam sejenis yang diketahui perbandingan luas penampangnya } \\
\text { dan perbandingan panjangnya }\end{array}$ & 0,64 & 0,08 & 0,18 \\
\hline 24 & $\begin{array}{l}\text { Menentukan suhu sambungan ke dua logam dengan panjang dan luas } \\
\text { yang sama tetapi berbeda konduktivitas termalnya }\end{array}$ & 0,72 & 0,14 & 0,09 \\
\hline
\end{tabular}

Peningkatan kompetensi tertinggi pada kelas eksperimen 1 terjadi pada kemampuan uji nomor 2 yakni kemampuan uji tentang mengkonversi satuan suhu dari derajat fahrenheit manjadi Kelvin. Sedangkan peningkatan terendah terjadi pada kemampuan uji nomor 17 yakni tentang menerapkan azas black untuk menentukan suhu kesetimbangan jika sejumlah cairan susu dimasukkan ke dalam kalorimeter yang berisi cairan kopi dengan suhu tententu dan kemampuan uji nomor 18 yakni tentang menyebutkan hubungan yang benar antara laju kalor secara konduksi dengan panjang logam, luas penampang dan perbedaan suhu antara ujung-ujung logam. Pada kelas eksperimen 1, terdapat data yang ganjil yakni terjadi penurunan kompetensi yakni pada kemampuan uji nomor 16 yaitu tentang menerapkan azas black untuk menentukan besarnya massa air panas yang harus ditambahkan pada 
air dingin untuk mencapai suhu kesetimbangan tertentu. Kemampuan uji ini termasuk salah satu kemampuan uji yang sulit. Tanda minus disebabkan oleh nilai pretest lebih besar dibandingkan dengan nilai posttest. Setelah ditelusuri, ternyata ditemukan bahwa jawaban pretest siswa pada nomor ini secara umum didasarkan pada tebakan.

Terkait kelas eksperimen 2, peningkatan kompetensi siswa tertinggi terjadi pada kemampuan uji nomor 14 yakni tentang menerapkan azas black untuk menentukan suhu setimbang jika air panas dimasukkan ke dalam bejana yang terbuat dari logam. Sedangkan peningkatan terendah terjadi pada kemampuan uji nomor 16 yakni tentang menerapkan azas black untuk menentukan besarnya massa air panas yang harus ditambahkan pada air dingin untuk mencapai suhu kesetimbangan tertentu dan juga kemampuan uji nomor 19 yakni tentang menjelaskan bahwa perpindahan kalor secara konveksi hanya terjadi pada zat cair dan gas.

Pada kelas kontrol, peningkatan kompetensi siswa tertinggi terjadi pada kemampuan uji nomor 22 yakni tentang menentukan besarnya konduktivitas termal logam jika laju rambatan kalor, luas permukaan dan perbedaan suhu antar ujung-ujung logam diketahui. Sedangkan peningkatan terendah terjadi pada kemampuan uji nomor 5 yakni tentang mengkonversi suhu suatu benda dari satuan celcius ke satuan lainnya.

\section{Peningkatan Kompetensi Siswa pada Kemampuan yang Diujinasionalkan untuk Materi Kalor}

Peningkatan kompetensi siswa baik pada kelas eksperimen 1, eksperimen 2 maupun kelas kontrol dapat ditelusuri dengan menghitung besarnya gain skor yang dinormalisasi $\langle g\rangle$ pada ketiga kelas tersebut. Persentase pencapaian rata-rata nilai pretest, posttest dan $\langle g\rangle$ untuk hasil uji kompetensi siswa pada materi kalor ditunjukkan pada Gambar 4.

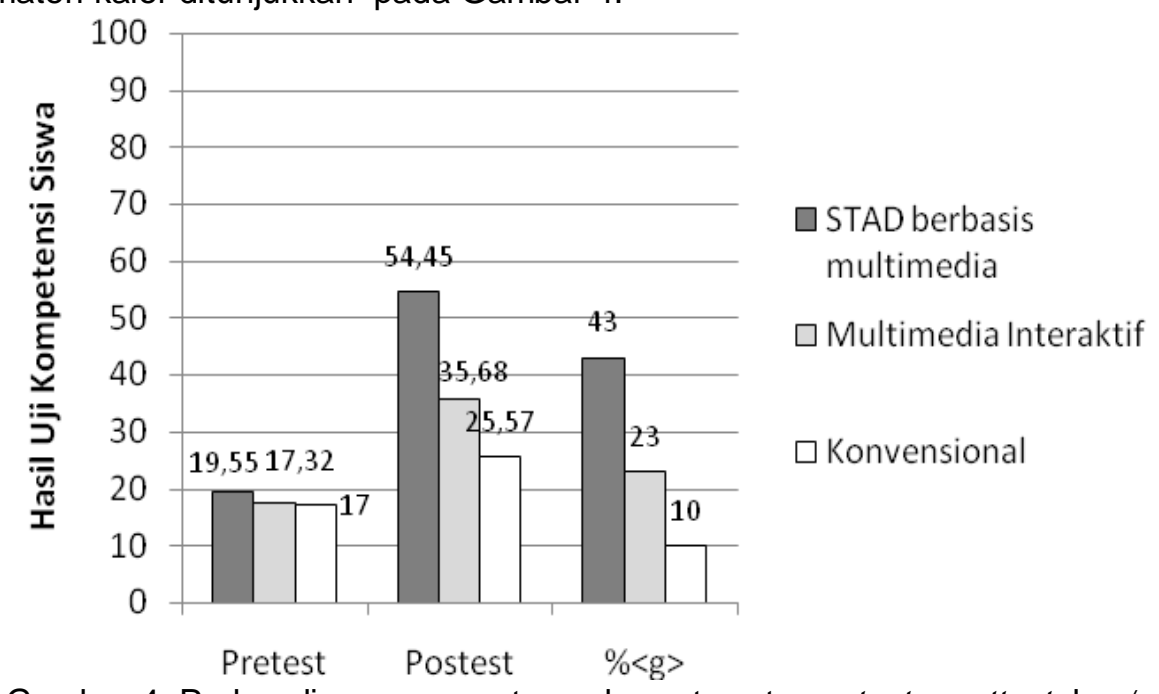

Gambar 4. Perbandingan persentase skor rata-rata pretest, posttest dan $\langle g\rangle$

Berdasarkan gambar 4, terlihat bahwa kompetensi siswa pada kemampuan uji yang diujinasionalkan pada materi kalor mengalami peningkatan setelah mengikuti pembelajaran baik pada kelas eksperimen 1, eksperimen 2 maupun kelas kontrol. Rata-rata nilai $\langle g\rangle$ pada kelas eksperimen 1 sebesar 0,43 (sedang), kelas eksperimen 2 sebesar 0,23 (rendah) dan kelas kontrol sebesar 0,10 (rendah). Berdasarkan hal tersebut, terlihat bahwa peningkatan kompetensi siswa pada kemampuan yang diujinasionalkan untuk kelas eksperimen 1 lebih tinggi dari kelas eksperimen 2 dan kelas kontrol. Hasil pengolahan data $\langle g\rangle$ secara statistik ditunjukkan pada Tabel 5. 
Tabel 5. Hasil Pengolahan Statistik Data $\langle g\rangle$

\begin{tabular}{lccc}
\hline Keterangan & Exp. 1 & Exp. 2 & Kontrol \\
\hline Rata-rata $\langle g\rangle$ & 0,43 & 0,23 & 0,10 \\
One-Sample Kolmogorov-Smirnov Test (Sig.) & 0,771 & 0,390 & 0,365 \\
Test of Homogeneity of Variances (Sig.) & \multicolumn{3}{c}{0,001} \\
One-Way ANOVA & \multicolumn{3}{c}{ Fhitung $=19,445$} \\
Post Hoc Test & Exp.1- & Exp.1- & Exp.2- \\
& Exp. 2 & kontrol & kontrol \\
\hline
\end{tabular}

Uji normalitas dengan menggunakan One-Sample Kolmogorov-Smirnov Test diperoleh hasil bahwa data $\langle g\rangle$ ketiga kelas berdistribusi normal dengan signifikansi (Sig.) atau p-value masing-masing sebesar 0,771 untuk kelas eksperimen 1 dan 0,390 untuk kelas eksperimen 2 dan 0,365 untuk kelas kontrol. Uji homogenitas varians data antara ketiga kelas dengan menggunakan Levene Tes (Test of Homogeneity of Variances) menunjukkan bahwa varians data $\langle g\rangle$ adalah tidak homogen dengan signifikansi (Sig.) atau p-value sebesar 0,001.

Berdasarkan hasil uji perbedaan tiga rata-rata dengan menggunakan One-Way ANOVA diperoleh bahwa nilai $F_{\text {hitung }}=19,445$ yang lebih besar dari nilai $F_{\text {tabel }}\left(F_{(0,95)(2,71)}\right)$ sebesar 3,13. Hal ini menunjukkan bahwa terdapat perbedaan yang signifikan dalam peningkatan kompetensi siswa pada ketiga kelas tersebut.

Karena asumsi homogenitas tidak terpenuhi, maka uji lanjut perbedaan rata-rata dilakukan dengan uji Tamhane's $T_{2}$. Berdasarkan uji lanjut tersebut diperoleh bahwa terdapat perbedaan yang signifikan dalam peningkatan kompetensi siswa pada kemampuan yang diujinasionalkan antara kelas eksperimen 1 dengan kelas eksperimen 2, terdapat perbedaan yang signifikan dalam peningkatan kompetensi siswa pada kemampuan yang diujinasionalkan antara kelas eksperimen 1 dengan kelas kontrol dan terdapat perbedaan yang signifikan dalam peningkatan kompetensi siswa pada kemampuan yang diujinasionalkan antara kelas eksperimen 2 dengan kelas kontrol.

Berdasarkan hal tersebut dapat disimpulkan bahwa penggunaan MMI kalor dalam pembelajaran lebih dapat meningkatkan kompetensi siswa pada kemampuan yang diujinasionalkan dibandingkan dengan pembelajaran konvensional. Dilihat dari nilai $\langle g>$ dan Cohen's $d$ effect size yang diperoleh, maka peningkatan kompetensi siswa akan lebih meningkat jika MMI digunakan dalam pembelajaran dengan menerapkan model pembelajaran tertentu dalam hal ini model pembelajaran kooperatif STAD.

\section{PENUTUP}

Penggunaan multimedia interaktif (MMI) secara signifikan efektif dalam meningkatkan kompetensi siswa pada kemampuan yang diujinasionalkan khususnya pada materi kalor dibandingkan dengan pembelajaran konvensional. Peningkatan kompetensi siswa pada materi kalor lebih meningkat, ketika MMI kalor digunakan dalam seting pembelajaran dengan menerapkan model pembelajaran kooperatif STAD (Student Teams Achievement Divisions). Pemilihan model pembelajaran ini tertentunya telah mempertimbangkan situasi dan kondisi, karakteristik materi serta karakteristik siswa pada populasi penelitian.

Dalam implementasinya, pada sekolah dengan fasilitas komputer yang memadai, MMI kalor yang dihasilkan dapat diterapkan dengan seting pembelajaran berbantuan komputer (Computer Aided Instructions) atau pembelajaran berbasis komputer (Computer Based Instructions). Akan tetapi, pada sekolah dengan fasilitas komputer yang cukup memadai dan kurang memadai, MMI kalor yang dihasilkan dapat digunakan dengan seting pembelajaran berbantuan komputer (Computer Aided Instructions) dimana MMI kalor digunakan pada pembelajaran dengan menerapkan model pembelajaran kooperatif. Salah satu tipe dari model kooperatif yang dapat diterapkan adalah model pembelajaran kooperatif STAD (Student Teams Achievement Divisions). 


\section{UCAPAN TERIMAKASIH}

Ucapan terima kasih ditujukan kepada guru fisika dan siswa SMAN 7 Halmahera Barat yang telah menjadi mitra dalam penelitian ini.

\section{DAFTAR PUSTAKA}

Arsyad, A. (2010). Media Pembelajaran. Jakarta: PT RajaGrafindo Persada.

BSNP, Puspendik, Balitbang Kemdikbud. (2012). Laporan Hasil Ujian Nasional Tahun Pelajaran 2011/2012 v.1 (Software). Kemdikbud.

Hake, R. R. (1998). Interactive-engagement versus traditional methods: A six-thousand-student survey of mechanics test data for introductory physics courses. American journal of Physics, 66(1), 6474.

Kotrlik, J. W., Williams, H. A., \& Jabor, M. K. (2011). Reporting and Interpreting Effect Size in Quantitative Agricultural Education Research. Journal of Agricultural Education, 52(1), 132142.

Munadi. (2008). Media Pembelajaran. Ciputat: Gaung Persada (GP) Press.

Munir. (2012). Multimedia Konsep \& Aplikasi dalam Pendidikan. Bandung: Alfabeta.

Nandy, K. (2012). Understanding and Quantifying EFFECT SIZES. Tersedia: https://pdfs.semanticscholar.org/8a0f/c6e54919829d3c4f49284e0396b57a97d7cb.pdf [17 Desember 2017].

Rahman, M. H., Saprudin, S., Mubarak, H., \& Hamid, F. (2017). Evaluasi Program IbM Pendampingan Penyusunan Borang Akreditasi Bagi Sekolah Dasar Di Kota Ternate. Titian Ilmu: Jurnal IImiah Multi Sciences, 9(2), 59-65.

Rusman. (2012). Belajar dan Pembelajaran Berbasis Komputer; Mengembangkan Profesionalisme Guru Abad 21. Bandung : Alfabeta

Saprudin. (2015). Efektivitas Penerapan Model Kooperatif STAD Berbasis Multimedia untuk Meningkatkan Penguasaan Siswa SMA terhadap Kemampuan yang Diujinasionalkan Mata Pelajaran Fisika di Maluku Utara. Prosiding Simposium Nasional Inovasi dan Pembelajaran Sains 2015 (SNIPS 2015), ISBN: 978-602-19655-8-0, Halaman 529 - 532

Saprudin, S., Liliasari, L., \& Prihatmanto, A. S. (2017, September). Pre-Service Physics Teachers' Concept Mastery and the Challenges of Game Development on Physics Learning. In Journal of Physics: Conference Series (Vol. 895, No. 1, p. 012109). IOP Publishing.

Slavin, R.E. (2008). Cooperative Learning; Teori riset dan Praktik. Bandung: Nusa Media.

Thalheimer, W., \& Cook, S. (2002). How to calculate effect sizes from published research: A simplified methodology. Work-Learning Research, 1-9 